\title{
Promoting Effect of Glucocorticoids on the Differentiation of Human Adipocyte Precursor Cells Cultured in a Chemically Defined Medium
}

\author{
Hans Hauner," Gero Entenmann, ${ }^{*}$ Martin Wabitsch, ${ }^{\star}$ Danielle Gaillard, ${ }^{\ddagger}$ Gérard Ailhaud, ${ }^{*}$ \\ Raymond Negrel, ${ }^{\star}$ and Ernst Friedrich Pfeiffer* \\ ${ }^{*}$ Medizinische Klinik und Poliklinik, Universität Ulm, D-7900 Ulm, Federal Republic of Germany; ${ }^{\ddagger}$ Laboratoire de Biologie du \\ Développement du Tissu Adipeux, Centre de Biochimie (UPR 7300), Faculté des Sciences, Parc Valrose, 06034 Nice, France
}

\begin{abstract}
Stromal-vascular cells obtained from adult human subcutaneous adipose tissue were cultured in a chemically defined serum-free medium. In the presence of $0.2 \mathrm{nM}$ triiodothyronine and $0.5 \mu \mathrm{M}$ insulin, up to $25 \%$ of the cells were able to undergo terminal adipose differentiation within $18 \mathrm{~d}$, as assessed by lipid accumulation and the expression of lipoprotein lipase (LPL) and glycerol-3-phosphate dehydrogenase (GPDH) activities. Addition of cortisol resulted in a potent dose-dependent stimulation of the adipose differentiation process. Cortisol could be replaced by dexamethasone and partly by aldosterone, but not by sex steroids. The proportion of differentiated cells was dependent upon the age of the donor; when isolated from young adults, up to $70 \%$ of the stromal-vascular cells expressed the adipocyte phenotype as compared with $5-10 \%$ when the cells were isolated from the oldest subjects. An inverse relationship was observed between the age of the 27 normal-weight donors and the extent of GPDH expression after maintenance of the cells for $18 \mathrm{~d}$ in chemically defined medium supplemented with insulin, triiodothyronine, and cortisol $(r=-0.787, P<0.001)$. It is concluded that adult human adipose tissue still contains precursor cells that are able to undergo adipose differentiation in vitro. This improved culture system may offer the opportunity to characterize other adipogenic factors as well as antiadipogenic factors involved in the control of adipose tissue growth.
\end{abstract}

\section{Introduction}

The present knowledge regarding the cellularity of adipose tissue in man is mainly derived from fat cell sizing studies. Previous investigations of the adipose tissue cellularity have shown that both the number and size of existing fat cells contribute to the adipose tissue mass. It was originally believed that the number of fat cells is fixed during childhood and that childhood-onset obesity is associated with adipocyte hyperplasia, whereas adult-onset obesity was postulated to be characterized by fat cell enlargement only $(1,2)$. This concept was challenged by later studies showing that the formation of new fat cells can also occur in adult life. The degree of hyperplasia

Address reprint requests to Dr. Hauner, Abteilung Innere Medizin I, Medizinische Klinik und Poliklinik, Universität Ulm, Oberer Eselsberg, D-7900 Ulm, FRG. 1989.

Received for publication 2 March 1989 and in revised form 19 June

J. Clin. Invest.

(c) The American Society for Clinical Investigation, Inc. $0021-9738 / 89 / 11 / 1663 / 08 \quad \$ 2.00$

Volume 84, November 1989, 1663-1670 appeared to be well correlated with the severity of overweight independent of the time of onset (3). However, up to now, the characteristics of the cellular development of human adipose tissue, including that of overweight patients, are far from being understood.

It is now well established that fibroblast-like adipose precursor cells, capable of undergoing differentiation into adipose cells, are present in the adipose tissue of various species including man. The existence of these cells has been originally suggested by studies after the incorporation of radiolabeled thymidine into DNA of developing rat adipose tissues (4-6). Both histological studies (7) and studies with cultured stromal-vascular cells isolated from adipose tissue (8-11) provided evidence for the existence of specific adipocyte precursor cells in man. However, in the various attempts using culture conditions developed for animal models and clonal cell lines, a very limited number of human stromal-vascular cells, if any, was found to develop the characteristic adipocyte phenotypes.

We recently reported that the adipose conversion of cultured stromal-vascular cells from adipose tissue samples of adult humans in serum-containing medium was enhanced when the medium was supplemented with insulin, cortisol, and 1-methyl-3-isobutylxanthine (MIX), ${ }^{1}$ the latter compound being present for the first $3 \mathrm{~d}$ after confluence. Under these conditions, up to $5 \%$ of the cells developed biochemical and morphological characteristics of mature adipocytes (12). The differentiation of human adipose precursor cells was also demonstrated using a serum-free chemically defined medium. In the presence of supraphysiological concentrations of insulin, up to $20 \%$ of the cells accumulated lipid droplets and expressed lipoprotein lipase and glycerol-3-phosphate dehydrogenase (GPDH) activities (13). As shown in the present report, it is now possible to define conditions under which up to $70 \%$ of the stromal-vascular cells isolated from adipose tissue samples of young adults are able to undergo adipose conversion. With this serum-free medium containing insulin, triiodothyronine and glucocorticoids, the frequency of adipose conversion was strongly decreased as a function of the age of the donor.

\section{Methods}

Subjects. Adipose tissue samples were obtained from the subcutaneous abdominal depot of 17 male and 10 female adults in the age range between 20 and 83 yr undergoing elective abdominal surgery. Patients suffering from an inflammatory or malignant disease were excluded. The operations were carried out for the following reasons: 10 for herniotomy, 7 for cholecystectomy, 3 for abdominal vascular surgery, 3

1. Abbreviations used in this paper: GPDH, glycerol-3-phosphate dehydrogenase (EC 1.1.1.8); LPL, lipoprotein lipase (EC 3.1.1.34); MIX, 1-methyl-3-isobutylxanthine. 
for transabdominal colon or Sigma polypectomy, 2 for selective proximal vagotomy, and 1 for tubal ligation. All subjects were of normal weight as defined as a body mass index under $27.8 \mathrm{~kg} / \mathrm{m}^{2}$ for male and $27.3 \mathrm{~kg} / \mathrm{m}^{2}$ for females (14). All patients had a normal physical examination and routine laboratory tests were within normal limits. None of the subjects was under a reduction diet at the time of examination. The data on age and body mass index of the individual subjects are given in Table I. The procedure followed in this investigation has been approved by the Ethical Committee of the University of Ulm.

Isolation and culture of stromal-vascular cells. The isolation of stromal-vascular cells was performed according to the method originally described by Björntorp et al. (15) with some modifications. Tissue samples $(2-15 \mathrm{~g})$ from the individual donors were kept at room temperature in PBS containing $20 \mathrm{mg} / \mathrm{ml}$ BSA (Sigma Chemical Co.,

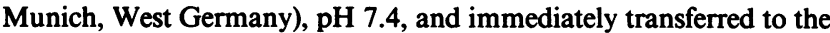
laboratory. The samples were repeatedly rinsed in PBS to remove any blood. Fibrous material and blood vessels were carefully dissected and discarded. The remaining tissue cut into small pieces $(10-20 \mathrm{mg})$ was digested in Krebs-Ringer buffered with $25 \mathrm{mM}$ Hepes containing 1.5 $\mathrm{mg} / \mathrm{ml}$ collagenase (CLS type I; Worthington Biochemical Corp., Freehold, NJ) and $20 \mathrm{mg} / \mathrm{ml} \mathrm{BSA}$ in a two-step procedure. The ratio between adipose tissue mass to incubation solution was $1 \mathrm{~g} / 4 \mathrm{ml}$. The first digestion was carried out for $30-45 \mathrm{~min}$ at $37^{\circ} \mathrm{C}$ under intermittent shaking. The dispersed tissue was filtered through a nylon mesh (pore size $250 \mu \mathrm{m}$ ). The remaining tissue was again digested for another $30 \mathrm{~min}$ and then filtered as above. More than $95 \%$ of the tissue was disaggregated by this procedure and the remaining fibrous material was discarded. Both cell suspensions were mixed and centrifuged for $10 \mathrm{~min}$ at $200 \mathrm{~g}$. The main contaminating cells of the cell suspension were erythrocytes, which constituted more than $90 \%$ of total cell number at this stage. The high contamination with red blood cells was found to markedly decrease cell adherence and proliferation. To eliminate red blood cells, the stromal-vascular cell fraction was incubated with a erythrocyte lysing buffer consisting of $0.154 \mathrm{M} \mathrm{NH}_{4} \mathrm{Cl}, 10 \mathrm{mM}$ $\mathrm{KHCO}_{3}$, and $0.1 \mathrm{mM}$ EDTA for $10 \mathrm{~min}$ at room temperature. Under these conditions, $>95 \%$ of red blood cells were lysed without damaging the nucleus-containing cells as assessed by Trypan blue exclusion. The application of the erythrocyte lysing buffer did not interfere with cell attachment, growth or differentiation of nucleus-containing cells in the stromal-vascular fraction. (Control experiments showed that treatment with the erythrocyte lysing buffer reduced dramatically the number of red blood cells previously mixed with 3T3-Ll cells, with no change in growth and differentiation of the latter.) After additional washing and centrifugation steps, the floating mature adipocytes were aspirated and the sedimented stromal-vascular fraction resuspended in DME/Ham's F-12 medium (1:1, vol/vol) supplemented with $10 \%$ FCS (Seromed, Berlin, West Germany), $100 \mathrm{U} / \mathrm{ml}$ penicillin, and 0.1 $\mathrm{mg} / \mathrm{ml}$ streptomycin (Boehringer, Mannheim, West Germany). Aliquots of the cell suspension were counted with a hemocytometer to determine the number of nucleus-containing cells. Cells were inoculated at various densities as indicated into 12-well plates, each well representing $\sim 4.5 \mathrm{~cm}^{2}$ (Linbro, Flow Laboratories, McLean, VA). After 16-20 h routinely used for cell attachment, cells were carefully washed with PBS to remove nonadhering material, mainly white blood cells and cell debris. Unless otherwise stated cells were inoculated at a density of $30,000 / \mathrm{cm}^{2}$. Under these conditions, cultures were usually in a preconfluent stage after the 20 -h period of cell attachment. Cells were then refed with a chemically defined serum-free medium consisting of DME/Ham's F-12 medium (1:1, vol/vol), $15 \mathrm{mM} \mathrm{NaHCO} 3,15$ $\mathrm{mM}$ Hepes, $33 \mu \mathrm{M}$ biotin, $17 \mu \mathrm{M}$ pantothenate, $0.5 \mu \mathrm{M}$ human insulin (kindly provided by Hoechst, Frankfurt, West Germany), $0.2 \mathrm{nM}$ triiodothyronine, and antibiotics as described previously (13). This medium is referred to as ITT medium (13). Cells were subsequently
Table I. Characteristics of the 27 Subjects

\begin{tabular}{|c|c|c|c|c|}
\hline No. & Sex & Age & Body mass index & GPDH activity \\
\hline & & & $\mathrm{kg} / \mathrm{m}^{2}$ & $m U / m g$ protein \\
\hline 1 & $\mathbf{M}$ & 38 & 27.1 & 1163 \\
\hline 2 & $\mathbf{M}$ & 22 & 27.7 & 1413 \\
\hline 3 & $\mathbf{M}$ & 47 & 24.0 & 530 \\
\hline 4 & $\mathbf{M}$ & 47 & 21.3 & 880 \\
\hline 5 & $\mathbf{M}$ & 20 & 22.7 & 760 \\
\hline 6 & $\mathbf{M}$ & 58 & 23.6 & 256 \\
\hline 7 & $\mathbf{M}$ & 20 & 21.6 & 1068 \\
\hline 8 & $\mathbf{M}$ & 21 & 22.7 & 1006 \\
\hline 9 & $\mathbf{M}$ & 67 & 24.8 & 145 \\
\hline 10 & $\mathbf{M}$ & 65 & 27.0 & 196 \\
\hline 11 & $\mathbf{M}$ & 24 & 24.5 & 1636 \\
\hline 12 & $\mathbf{M}$ & 42 & 27.4 & 932 \\
\hline 13 & $\mathbf{M}$ & 22 & 21.7 & 1151 \\
\hline 14 & $\mathbf{M}$ & 63 & 25.9 & 150 \\
\hline 15 & $\mathbf{M}$ & 52 & 26.7 & 337 \\
\hline 16 & $\mathbf{M}$ & 20 & 26.7 & 868 \\
\hline 17 & $\mathbf{M}$ & 82 & 25.5 & 235 \\
\hline 18 & $F$ & 48 & 20.7 & 252 \\
\hline 19 & $\mathbf{F}$ & 35 & 22.7 & 1162 \\
\hline 20 & $\mathbf{F}$ & 66 & 26.4 & 332 \\
\hline 21 & $\mathbf{F}$ & 45 & 27.0 & 519 \\
\hline 22 & $\mathbf{F}$ & 49 & 23.8 & 310 \\
\hline 23 & $\mathbf{F}$ & 83 & 24.0 & 288 \\
\hline 24 & $\mathbf{F}$ & 22 & 24.4 & 593 \\
\hline 25 & $\mathrm{~F}$ & 45 & 24.2 & 473 \\
\hline 26 & $\mathbf{F}$ & 54 & 26.6 & 296 \\
\hline 27 & $\mathbf{F}$ & 21 & 22.1 & 1086 \\
\hline
\end{tabular}

Cultures of stromal-vascular cells were obtained from the adipose tissue samples of the donors inoculated and cultured under standardized conditions as described in Methods (duplicate dishes). After culture for $18 \mathrm{~d}$ in ITT medium supplemented with $0.1 \mu \mathrm{M}$ cortisol, cells were harvested for the determination of GPDH activity.

maintained in this medium supplemented as indicated in the legends of Tables and Figures. Cultures were refed every 2-3 d. Human skin fibroblasts kindly provided by Dr. J. Ittner (University of Ulm, West Germany) and foreskin fibroblasts kindly provided by Dr. F. Bastiani (University of Nice, France) were also used in this study.

Cells were regarded as differentiated by morphological criteria when, after acquiring a round shape, their cytoplasm was completely filled with multiple lipid droplets (also assessed by Oil Red O staining). The proportion of differentiated cells was estimated in some experiments by direct counting under the microscope total and differentiated cells present as a monolayer, using a micrometer (Zeiss Oberkochen, West Germany) at a 100 -fold magnification.

Factor VIII antigen immunofluorescence labeling. After elimination of red blood cells, endothelial cells represent the main contaminant of the stromal-vascular fraction. However, this cell type can be easily detected by its cobblestone appearance and is characterized by the presence of Factor VIII antigen. The number of endothelial cells was estimated by means of immunolabeling of Factor VIII antigen (16). Briefly, cells were seeded at 20,000 cells $/ \mathrm{cm}^{2}$, grown to confluence on glass slides in 4-well chamber systems (Miles Scientific, Naperville,

Figure 1. Morphology of differentiating stromal-vascular cells from human adipose tissue. After seeding in serum-containing medium (for 16 h), cells were cultured in ITT medium supplemented with $0.1 \mu \mathrm{M}$ cortisol for $18 \mathrm{~d}$. $(A)$ Cells on day 0 and $(B)$ cells on day 18 before harvesting. $\times 100$. 

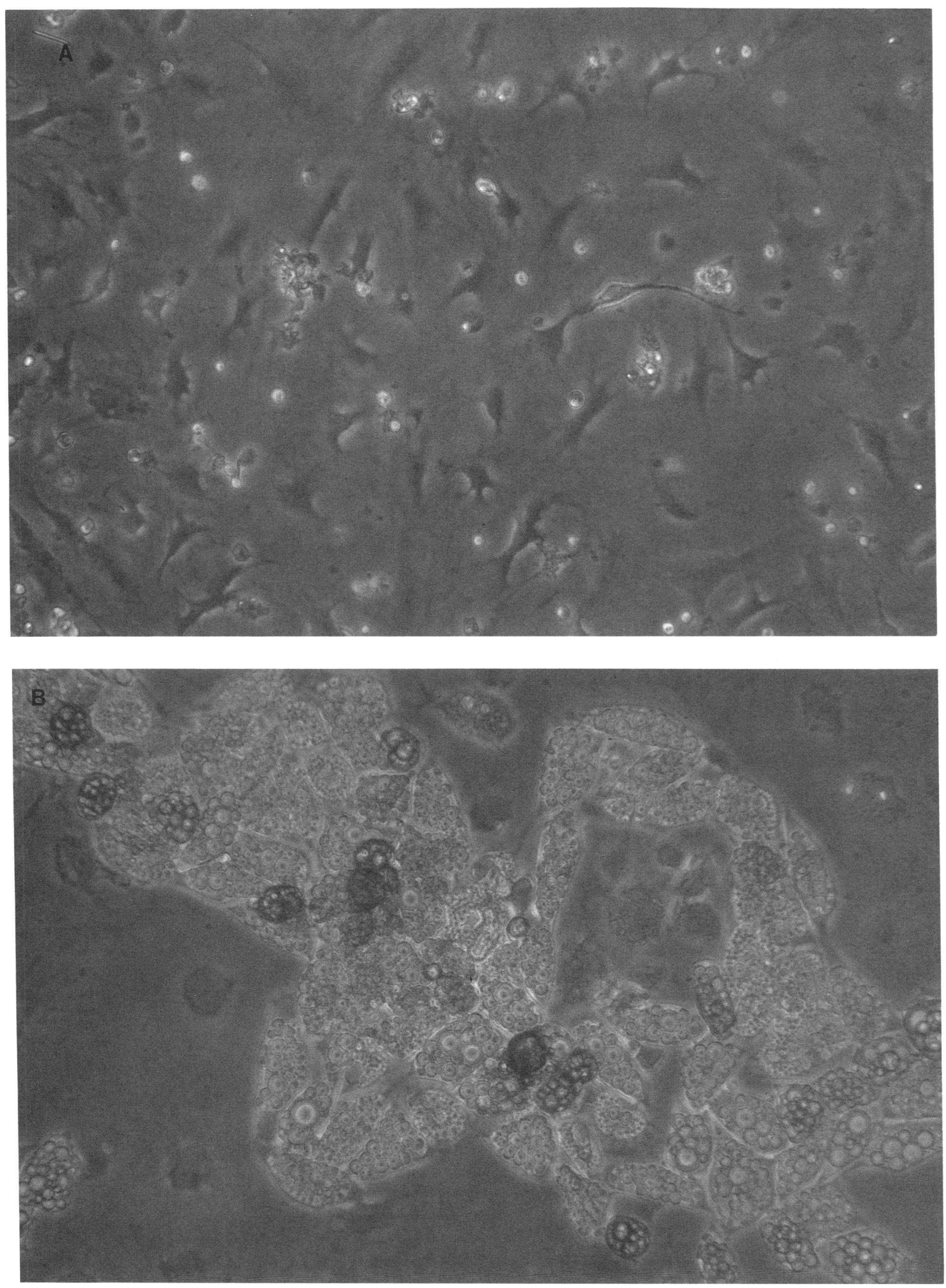
IL), rinsed with PBS (pH 7.2) and fixed in acetone for $10 \mathrm{~min}$ at $0^{\circ} \mathrm{C}$. Cultures were then incubated in a moist chamber at $37^{\circ} \mathrm{C}$ for $30 \mathrm{~min}$ first with rabbit anti-serum Factor VIII (Dianova, Hamburg, West Germany) or nonimmune rabbit IgG (Dianova) and second, after thorough rinsing in PBS, with fluorescein-conjugated anti-rabbit IgG (Dianova). The number of fluorescent cells was counted by fluorescence microscopy (Zeiss).

Enzymatic and chemical determinations. After $18 \mathrm{~d}$ of maintenance under culture conditions as indicated, cells were washed with PBS (pH 7.4), harvested in prechilled $25 \mathrm{mM}$ Tris- $\mathrm{HCl}$ buffer containing $1 \mathrm{mM}$ EDTA ( $\mathrm{pH} 7.5$ ), and homogenized using a Branson sonifier (Branson Sonic Power Co., Danbury, CT). GPDH activity was determined spectrophotometrically in the sonicated cell extracts (17). The assay mixture contained $100 \mathrm{mM}$ triethanolamine $\mathrm{HCl}$ buffer (pH 7.5), $2.5 \mathrm{mM}$ EDTA, $0.12 \mathrm{mM}$ NADH, $0.1 \mathrm{mM}$ mercaptoethanol, and to start the reaction, $0.2 \mathrm{mM}$ dihydroxyacetone phosphate. Results are expressed as $\mathrm{mU} / \mathrm{mg}$ protein, $1 \mathrm{mU}$ being equal to the oxidation of 1 nmol NADH/min.

For the determination of lipoprotein lipase (LPL) activity, cells suspended in cold $50 \mathrm{mM} \mathrm{NH} / \mathrm{NH}_{4} \mathrm{Cl}$ buffer ( $\left.\mathrm{pH} 8.1\right)(0.4 \mathrm{ml}$ per dish) containing $3 \mathrm{U} / \mathrm{ml}$ heparin were sonicated and centrifuged at 500 $g$ for $5 \mathrm{~min}$. LPL activity was measured using suitable amounts of the resulting supernatant fraction and a serum-activated emulsion of tri $\left[9,10-{ }^{3} \mathrm{H}\right]$ oleylglycerol (Amersham-Buchler, Braunschweig, West Germany) stabilized with phosphatidylcholine (Sigma Chemical Co., St. Louis, MO) as described earlier (18). $1 \mathrm{mU}$ of LPL activity represented the serum-dependent release of $1 \mathrm{nmol}$ of fatty acid/min. A protein precipitation technique using sodium deoxycholate and TCA was applied to measure protein contents without interfering lipids (19). The triacylglycerol content of the cultures was measured using a commercially available test kit (Boehringer).

Results are expressed as means \pm SE. Correlation coefficients were calculated using linear regression analysis.

\section{Results}

Stromal-vascular cells were obtained by a two-step collagenase digestion of adipose tissue samples and initially maintained for 16-20 $\mathrm{h}$ in serum-containing medium to allow cell attachment. At that time, cells were in a preconfluent stage and exhibited a fibroblast-like morphology (Fig. $1 \mathrm{~A}$ ). Cells were completely devoid of lipid droplets as assessed by Oil Red $\mathrm{O}$ staining and measurement of triacylglycerol content. The cultures of stromal-vascular cells were essentially free of endothelial cells as assessed by direct examination under the microscope. Furthermore, immunofluorescence labeling using a specific antiserum directed against Factor VIII antigen indicated that the percentage of endothelial cells was usually $<1 \%$. Cells were subsequently exposed to ITT medium supplemented with $0.1 \mu \mathrm{M}$ cortisol. The cells started to accumulate small refringent lipid droplets within $8 \mathrm{~d}$ and were able 4-12 d later to develop an adipocyte-like morphology, the cytoplasm being filled with triacylglycerol droplets (Fig. $1 B$ ), which stained readily with Oil Red $O$. Under these conditions, up to $70 \%$ of the stromal-vascular cells from young adults were filled with triacylglycerol droplets after $18 \mathrm{~d}$ of culture. It must be recalled that a good correlation between the proportion of differentiated triacylglycerol-containing cells and the specific activity of GPDH occurred both for human stromal-vascular cells (12) and mouse Ob17 cells (20). Furthermore, histochemical staining of GPDH was only observed in clusters of lipid-containing cells (13). In agreement with the number of lipid-filled cells detected microscopically, the GPDH activities remained below the detection limit from day 0 to day 4 , became measur-

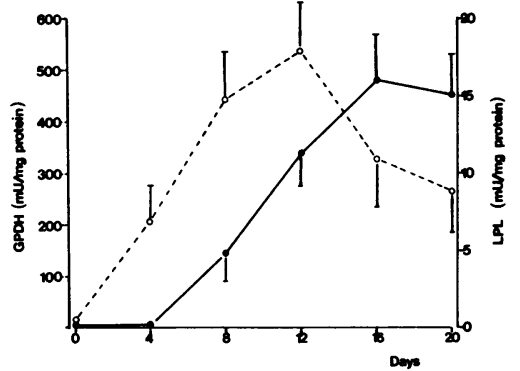

Figure 2. Time-course of the development of LPL and GPDH activities in cultured stromalvascular cells from human adipose tissue. Cells inoculated as described in Methods were subsequently cultured for $20 \mathrm{~d}$ in ITT medium supplemented with $0.1 \mu \mathrm{M}$ cortisol. Duplicate cultures were harvested every $4 \mathrm{~d}$ from day 0 for the determination of LPL (0) and GPDH (•) activities (mean \pm range of two experiments).

able at day 8 and sharply increased, reaching maximum levels at day 16 (Fig. 2). LPL, the activity of which was undetectable at day 0 , was expressed at a significant level $(7 \mathrm{mU} / \mathrm{mg}$, i.e., $40 \%$ of the maximal activity) as early as day 4 , reached a maximal level at days 8-12 and decreased thereafter (Fig. 2). Thus it appears that the emergence of LPL precedes that of GPDH. It is interesting to note that adult human skin fibroblasts as well as infant foreskin fibroblasts cultured under identical conditions neither exhibit changes in cell morphology nor express LPL and GPDH activities nor accumulate lipid droplets (data not shown and reference 13).

The extent of adipose conversion was strongly dependent upon the inoculation density. As demonstrated in Fig. 3, the highest GPDH activity values were obtained at a seeding density range of 30,000 to 40,000 cells $/ \mathrm{cm}^{2}$. The time of exposure to serum-containing medium before exposure to serum-free medium appeared also to be important: the GPDH activity was maximal when cells were changed to the serum-free medium $4 \mathrm{~h}$ after inoculation, which was a time period sufficient to allow cell attachment (Table II). In contrast, exposure to serum-containing medium for $90-180 \mathrm{~h}$ led to a significant decrease of the GPDH activity by $\sim 70 \%$ and $85 \%$, respectively. This loss of differentiation capacity was accompanied by a significant increase in cellular protein content, reflecting a sustained proliferation visible by microscope examination. After maintainance in serum-free medium of confluent cells previously cultured in the presence of serum, a nearly complete loss of differentiation capacity was observed (Table II).

Consideration was next given to the role of glucocorticoids. In ITT medium, the adipose conversion of stromal-vascular cells of infants (13) or adults (see Fig. 5) did not exceed $20 \%$ of the cell population and the corresponding GPDH activity values were in the range of 50 to $400 \mathrm{mU} / \mathrm{mg}$ protein; the addition of glucocorticoids considerably enhanced the percentage of differentiated cells and the GPDH activity. This effect of glucocorticoids was dependent upon the presence of insulin, since adipose conversion was hardly detectable in its absence: under these conditions, no lipid accumulation was observed and the GPDH activity values remained in the range of 30 to $70 \mathrm{mU} / \mathrm{mg}$ protein. The number of differentiated cells was dependent upon the glucocorticoid concentration. In combination with $0.5 \mu \mathrm{M}$ insulin, cortisol was able to enhance the adipose conversion in a dose-dependent manner as illustrated by the increase in GPDH specific activity (Fig. 4). Its effect was already significant at $1 \mathrm{nM}$ whereas the GPDH activity was 4.2 -fold above the basal level at $1 \mu \mathrm{M}$ cortisol. Cor- 


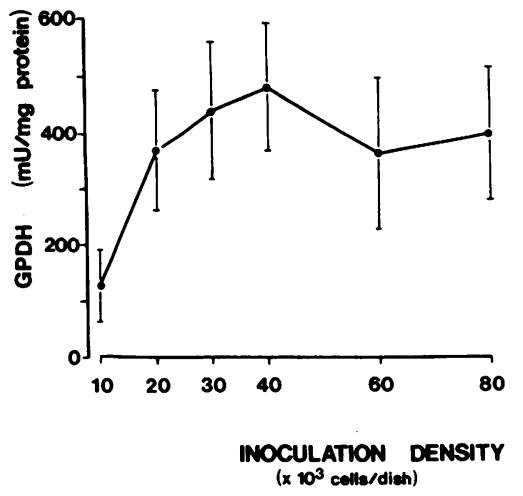

Figure 3. Dependence of GPDH activity on the inoculation density of cultured stromal-vascular cells from human adipose tissue. Cells were seeded at the densities indicated and maintained for $16 \mathrm{~h}$ in serum-supplemented medium. They were subsequently fed with ITT medium supplemented with $0.1 \mu \mathrm{M}$ cortisol. After $18 \mathrm{~d}$ in culture, cells were harvested for the determination of GPDH activity (mean \pm range of two separate experiments performed with duplicate dishes).

tisol could be replaced by dexamethasone and partly by aldosterone. In contrast, the sex steroids 17-beta estradiol and progesterone failed to enhance the adipose conversion process (Table III).

Although a long exposure time to cortisol was used in most experiments, a 3-d exposure to this hormone was sufficient to enhance both the number of differentiated cells visible under microscope and the GPDH activity (Table IV). Increasing the exposure time to cortisol up to $18 \mathrm{~d}$ led to a moderate increase in that activity. The single addition of MIX as a cAMP-elevating agent (21), during the first 3 or $6 \mathrm{~d}$, was able to increase the GPDH activity in the absence or in the presence of cortisol. The effect of MIX appears to be additive to that of cortisol (Table IV) and to accelerate the adipose conversion process (not shown). The triacylglycerol content of cells maintained

Table II. Effect of Time of Incubation in Serum-containing Medium on GPDH Activity

\begin{tabular}{cc}
\hline $\begin{array}{c}\text { Time of incubation in } \\
\text { serum-containing medium }\end{array}$ & GPDH activity \\
\hline$h$ & $m U / m g$ protein \\
Primary cultures & \\
4 & $658 \pm 120$ \\
$16-20$ & $585 \pm 135$ \\
$40-48$ & $463 \pm 78$ \\
90 & $154 \pm 36$ \\
180 & $81 \pm 14$ \\
First subculture & $55 \pm 19$ \\
Second & \\
subculture & ND \\
\end{tabular}

ND, not detectable.

Stromal-vascular cells from human adipose tissue were seeded at $30,000 / \mathrm{cm}^{2}$ and maintained in serum-containing medium for the time periods indicated. Primary cultures were kept for another $18 \mathrm{~d}$ in ITT medium supplemented with $0.1 \mu \mathrm{M}$ cortisol. Secondary cultures (first and second subcultures) were grown to confluence in serum-supplemented medium, trypsinized, plated in serum-supplemented medium for $20 \mathrm{~h}$ and then shifted and maintained for $18 \mathrm{~d}$ under serum-free conditions as above. GPDH activity was measured as described in Methods (means $\pm \mathrm{SE}$ of three separate experiments performed on duplicate dishes).

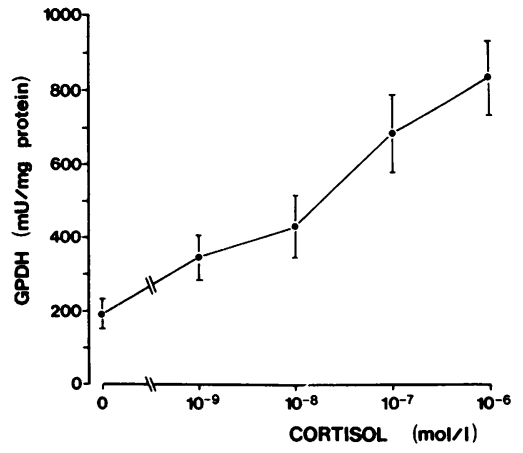

Figure 4. Dose-response relationship of cortisol to GPDH activity in cultured stromal-vascular cells from human adipose tissue. After inoculation in serum-containing medium for 16 $\mathrm{h}$, cells were maintained for $18 \mathrm{~d}$ in ITT medium supplemented or not with increasing concentrations of cortiso

as indicated. Cells were then harvested for the determination of GPDH activity. Mean \pm SE of three separate experiments performed on duplicate dishes.

under the optimal conditions of Table IV was increased 3.3fold ( $100 \mu \mathrm{g} / \mathrm{dish}$ vs. $30 \mu \mathrm{g} / \mathrm{dish})$ as compared with cells maintained in ITT medium. Since the culture medium did not contain exogenous lipids, the accumulation of triacylglycerol droplets was exclusively the result of de novo synthesis, in agreement with the high capacity of human adipocyte precursors to incorporate glucose into cellular lipids (13).

The comparison of adipose conversion obtained in serumfree and serum-containing media, both supplemented with cortisol $(0.1 \mu \mathrm{M})$ and insulin $(0.5 \mu \mathrm{M})$, revealed a striking difference. In serum-containing medium, the percentage of differentiating cells was much lower as compared with that obtained in serum-free conditions. GPDH activity was only $3-4 \%$ of the value obtained in serum-free medium ( $28 \pm 6$ vs. $893 \pm 165 \mathrm{mU} / \mathrm{mg}$ protein, $P<0.001$ ); similar results were obtained whether or not MIX was present during the first $3 \mathrm{~d}$ $(38 \pm 8$ vs. $1,069 \pm 183 \mathrm{mU} / \mathrm{mg}$ protein, $P<0.001)$. The protein content was 3.4-fold higher in cultures kept in serum-containing medium as compared with serum-free medium ( $168 \pm 51$ vs. $49 \pm 16 \mu \mathrm{g}$ protein/dish), suggesting that the sustained growth, which was visible under microscope, was induced by serum mitogenic factors.

Table III. Effect of Other Steroid Hormones on the Expression of GPDH Activity in Stromal-Vascular Cells Derived

from Human Adipose Tissue

\begin{tabular}{cc}
\hline Hormone & GPDH activity \\
\hline & $\%$ of the maximum \\
Cortisol & $27 \pm 2$ \\
Dexamethasone & $83 \pm 5$ \\
Aldosterone & 100 \\
$17 \beta$-estradiol & $70 \pm 4$ \\
Progesterone & $25 \pm 8$ \\
\end{tabular}

$16 \mathrm{~h}$ after inoculation in serum-containing medium, cells were cultured in ITT medium in the absence or presence of $0.1 \mu \mathrm{M}$ of the various steroid hormones. Cultures were harvested after $18 \mathrm{~d}$ for the determination of GPDH activity. The values expressed in percentage of the maximum specific activity for medians \pm ranges for two independent experiments. The specific activities of GPDH were 86 and $212 \mathrm{mU} / \mathrm{mg}$ without hormone supplementation and, respectively, 360 and $724 \mathrm{mU} / \mathrm{mg}$ in the presence of $0.1 \mu \mathrm{M}$ dexamethasone. 
Table IV. Effect of Exposure Time to Cortisol and/or MIX on the GPDH Activity in Stromal-Vascular Cells from Human Adipose Tissue

\begin{tabular}{lcc}
\hline \multicolumn{1}{c}{ Additions } & Exposure time & GPDH activity \\
\hline & $d$ & $m U / m g$ protein \\
Cortisol & - & $161 \pm 17$ \\
Cortisol & 3 & $438 \pm 101$ \\
Cortisol & 6 & $484 \pm 86$ \\
MIX & 18 & $568 \pm 73$ \\
MIX & 3 & $254 \pm 52$ \\
Cortisol* + MIX & 6 & $291 \pm 58$ \\
Cortisol* + MIX $^{*}$ & 3 & $779 \pm 116$ \\
& 6 & $936 \pm 145$ \\
\hline
\end{tabular}

* Cortisol was present during the whole incubation period ( $18 \mathrm{~d})$. $16 \mathrm{~h}$ after inoculation in serum-containing medium, cells were subsequently cultured in ITT medium supplemented or not with cortisol $(0.1 \mu \mathrm{M})$ and/or MIX $(0.25 \mathrm{mM})$ for the times indicated. $18 \mathrm{~d}$ later, cells were harvested for the determination of GPDH activity. Means \pm SE of three separate experiments performed on duplicate dishes.

The number of stromal-vascular cells capable to differentiate into adipose cells, i.e., to express GPDH, was dependent upon the age of the donor. GPDH activities were measured in cultures obtained from 27 adults ranging from 20 to $83 \mathrm{yr}$ in age and maintained for $18 \mathrm{~d}$ in ITT medium supplemented with $0.1 \mu \mathrm{M}$ cortisol. As shown in Fig. 5 by plotting the GPDH specific activity measured at day 18 as a function of the donor age, there was a significant inverse relationship $(r=-0.787, P$ $<0.001)$. This inverse relationship was observed for both sexes (males, $r=-0.832, P<0.001$; females: $r=-0.674, P<0.01$ ) and led also to a reduction in the variability between subjects after 40-50 yr of age. The GPDH activities seemed to be slightly higher in cultures from male subjects than from female subjects, but a definite statement regarding this point cannot be made owing to disparities both in the number and the age distribution of male and female subjects.

\section{Discussion}

The present report defines the hormonal requirements for the differentiation of stromal-vascular cells, isolated from human

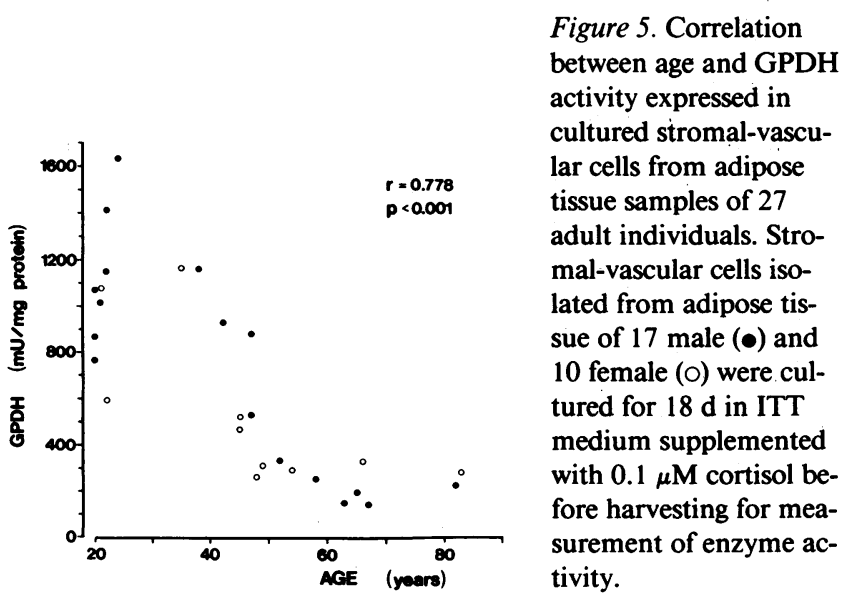

adipose tissue, into adipose cells. These in vitro studies were based upon the chemically defined serum-free medium (ITT medium) recently developed by Deslex et al. $(13,22)$. In contrast to serum-containing media, up to $70 \%$ of the stromal-vascular cells obtained from young adults were found to convert into adipose cells in ITT medium when supplemented with glucocorticoids. This finding is in line with our previous studies performed in serum-containing medium which showed that glucocorticoid hormones, in the presence of insulin, play the role of adipogenic factors able to induce the adipose conversion process in human cells (12). The situation described herein for human cells is similar to the findings reported for stromal-vascular cells isolated from adipose tissue of young rats where most of the stromal-vascular cells, if not all, were able to convert into adipose cells $(22,23)$. The early development of LPL, as compared with that of GPDH and also with triacylglycerol accumulation, is in very good agreement with the situation already described in mouse preadipocyte cells (24-26). Thus LPL appears to be also an early marker of differentiation in human preadipocytes.

In agreement with previous studies performed with rat and sheep adipose precursor cells in primary culture $(22,27,28)$, our data indicate also that the presence of serum reduces dramatically the frequency of adipose conversion accompanied by a decrease of the GPDH activity by $>95 \%$ as compared with serum-free conditions. Among hypotheses to explain the lower frequencies of adipose conversion so far reported for rodent and human adipose precursor cells in serum-supplemented media $(8-13,26)$, it could be envisioned that the high mitogenic potency of serum, which is reflected by a significant increase in the cell number, leads by means of over-proliferation to a loss of specific early markers of preadipose cells, e.g., to a cell "decommitment." This phenomenon was reported to be the case in Ob17 preadipose cells $(24,29)$. Alternatively, it cannot be excluded that antiadipogenic factors are indeed present in serum: for instance tumor necrosis factor and transforming growth factor- $\beta$ have been shown to decrease the expression of GPDH mRNA in Ob17 adipose cells independently of a growth-promoting activity (29), and this could also well be the case in other observations showing the inhibitory effects of the tumor necrosis factor, transforming growth factor- $\beta$, fibroblast growth factor and platelet-derived growth factor on adipose conversion (30-33).

It should be noted that stromal-vascular cells from human adipose tissue inoculated and maintained in the absence of serum, are able to differentiate to a similar extent as shown in this study where cells were inoculated in serum-containing medium for the attachment period and maintained in serumfree medium (Hauner, H., and G. Entenmann, manuscript in preparation). The high proportion of cells able to develop the adipocyte phenotype under our defined culture conditions indicates that the stromal-vascular fraction is much less heterogenous than originally thought (8-11) and that adipose tissue from donors at any age contains a remarkable pool of adipose precursor cells. The decrease in the capacity of differentiation as a function of age is likely related to the decreased susceptibility of the remaining precursor cells to respond to extracellular signals and/or a decreased proportion of these precursor cells. Such age-dependency of differentiation capacity has been also observed in rat $(22,34,35)$ and at a given age with respect to the anatomical site of the fat depot (36). The state at which these adipose precursor cells are present in vivo remains un- 
known. However, it must be recalled that dormant preadipose cells, containing pOb24 mRNA as an early marker, have been characterized in various adipose tissues of very old mice (25). Taken together, these observations suggest that dormant preadipose cells are present in rodent and human adipose tissues and are involved in the acquisition of new fat cells during adult life $(3,11,37,38)$.

The function of glucocorticoids for the development of adipocytes from precursor cells has been originally suggested by Rubin et al. (39) and recently investigated by Wiederer and Löffler (23). Glucocorticoid hormones, further identified as the main components of the adipogenic activity present in human serum (40), are indeed of great importance for the adipose conversion of stromal-vascular cells derived from human adipose tissue. The development of a fibroblast-like precursor cell to a mature fat cell is accompanied by a controlled sequence of changes in gene expression reflected by the de novo synthesis of enzymes involved in lipogenesis and other differentiation-specific proteins (41-43), in which regulation of the expression of various genes by glucocorticoids has been described $(43,44)$. The positive effect of glucocorticoids on adipose conversion is amplified by a cAMP-elevating agent (Table IV). In that respect, it is interesting to note that a sustained level of CAMP, coupled to the activation of the polyphosphoinositide breakdown, has been shown recently to be required for the differentiation of mouse Ob17 cells in serumfree medium (20). Furthermore, carbaprostacyclin, a stable analogue of prostacyclin known to be synthesized by murine and human preadipocytes, which is a potent activator of cAMP production and which has been shown to trigger terminal differentiation of $\mathrm{Ob} 17$ cells behaves also as an adipogenic factor for the differentiation of human stromal-vascular cells in ITT medium (45). Since glucocorticoids behave as mitogenic-adipogenic stimuli for $\mathrm{Ob} 17$ cells having expressed early markers (Gaillard, D., M. Wabitsch, and R. Négrel, manuscript in preparation), it is suggested that in man, like in mouse, glucocorticoids modulate the terminal differentiation of dormant preadipose cells.

The present culture system may provide a new tool to study, on the one hand the contribution of the human adipocyte precursor pool to the pathogenesis of obesity, and on the other hand, the hormonal control of the recruitment of new fat cells in man, including the possible involvement of paracrine/ autocrine factors.

\section{Acknowledgments}

We express our gratitude to Mss. Martina Schroff, Hannelore Wüst and Martine Cazalès for expert technical assistance. We are indebted to Professor Hartel and his staff from the Department of Surgery, Bundeswehrkrankenhaus Ulm, for their support in providing the adipose tissue samples.

\section{References}

1. Hirsch, J., and J. L. Knittle. 1970. Cellularity of obese and non-obese human adipose tissue. Fed. Proc. 29:1516-1521.

2. Salans, L. B., S. W. Cushman, and R. E. Weisman. 1973. Studies on human adipose tissue. Adipose cell size and number in non-obese and obese patients. J. Clin. Invest. 52:929-941.

3. Hirsch, J., and B. Batchelor. 1976. Adipose tissue cellularity in human obesity. Clin. Endocrinol. Metab. 5:299-311.

4. Hollenberg, C. H., and A. Vost. 1968. Regulation of DNA syn- thesis in fat cells and stromal elements from rat adipose tissue. J. Clin. Invest. 47:2485-2498.

5. Pilgrim, C. 1971. DNA synthesis and differentiation in developing white adipose tissue. Dev. Biol. 26:69-76.

6. Greenwood, M. R. C., and J. Hirsch. 1974. Postnatal development of adipocyte cellularity in the normal rat. J. Lipid Res. 15:874883.

7. Dardick, I., W. J. Poznansky, I. Waheed, and G. Setterfield. 1976. Ultrastructural observations on differentiating human preadipocytes cultured in vitro. Tissue \& Cell. 8:561-571.

8. Poznanski, W. J., J. Waheed, and R. Van. 1973. Human fat cell precursors. Morphologic and metabolic differentiation in culture. Lab. Invest. 29:570-576.

9. Dixon-Shanies, D., J. Rudick, and J. L. Knittle. 1975. Observations on the growth and metabolic functions of cultured cells derived from human adipose tissue. Proc. Soc. Exp. Biol. Med. 149:541-545.

10. Van, R. L. R., C. E. Bayliss, and D. A. K. Roncari. 1976. Cytological and enzymological characterization of adult human adipocyte precursors in culture. J. Clin. Invest. 58:699-704.

11. Pettersson, P., R. Van, M. Karlsson, and P. Björntorp. 1985. Adipocyte precursor cells in obese and non-obese humans. Metab. Clin. Exp. 34:808-812.

12. Hauner, H., P. Schmid, and E. F. Pfeiffer. 1987. Glucocorticoids and insulin promote the differentiation of human adipocyte precursor cells into fat cells. J. Clin. Endocrinol. Metab. 64:832-835.

13. Deslex, S., R. Négrel, C. Vannier, J. Etienne, and G. Ailhaud. 1987. Differentiation of human adipocyte precursors in a chemically defined serum-free medium. Int. J. Obes. 11:19-27.

14. Abraham, S., M. D. Carroll, M. F. Najjar, and R. Fulwood. 1983. Obese and overweight adults in the United States. National Center for Health Statistics. Hyattsville, MD: DHHS publication (PHS) 83-1680.

15. Björntorp, P., M. Karlsson, H. Pertoft, P. Pettersson, L. Sjöstrom, and U. Smith. 1978. Isolation and characterization of cells from rat adipose tissue developing into adipocytes. J. Lipid Res. 19:316324.

16. Björntorp, P., G. K. Hansson, L. Jonasson, P. Pettersson, and G. Sypniewska. 1983. Isolation and characterisation of endothelial cells from the epididymal fat pad of the rat. J. Lipid Res. 24:105-112.

17. Pairault, J., and H. Green. 1979. A study of the adipose conversion of suspended $3 \mathrm{~T} 3$ cells by using glycerophosphate dehydrogenase as differentiation marker. Proc. Natl. Acad. Sci. USA. 76:51385142 .

18. Spooner, P. M., S. S. Chernick, M. M. Garrison, and R. O. Scow. 1979. Development of lipoprotein lipase activity and accumulation of triacylglycerol in differentiating 3T3-L1 adipocytes: effects of prostaglandin $\mathrm{F}_{2 \alpha}$, 1-methyl-3-isobutylxanthine, prolactin and insulin. J. Biol. Chem. 254:1305-1311.

19. Peterson, G. L. 1977. A simplication of the protein assay of Lowry et al. Which is more generally applicable? Anal. Biochem. 83:346-356.

20. D. Gaillard, R. Négrel, M. Lagarde, and G. Ailhaud. 1989. Requirement and role of arachidonic acid in the differentiation of preadipose cells. Biochem. J. 257:389-397.

21. Elks, M. L., and V. C. Manganiello. 1984. Selective effects of phosphodiesterase inhibitors on different phosphodiesterases, adenosine $3^{\prime}, 5^{\prime}$-monophosphate metabolism, and lipolysis in 3T3-L1 adipocytes. Endocrinology. 115:1262-1268.

22. Deslex, S., R. Négrel, and G. Ailhaud. 1987. Development of a chemically defined, serum-free medium for differentiation of rat adipose precursor cells. Exp. Cell Res. 168:15-30.

23. Wiederer, O., and G. Löffler. 1987. Hormonal regulation of the differentiation of rat adipocyte precursor cells in primary culture. $J$. Lipid Res. 28:649-658.

24. Amri, E., C. Dani, A. Doglio, P. Grimaldi, and G. Ailhaud. 1986. Coupling of growth arrest and expression of early markers during adipose conversion of preadipocyte cell lines. Biochem. Biophys. Res. Commun. 137:903-910. 
25. Ailhaud, G., C. Dani, E. Amri, P. Djian, C. Vannier, A. Doglio, C. Forest, D. Gaillard, R. Négrel, and P. Grimaldi. 1989. The molecular basis of adipose tissue growth. In Obesity in Europe: I. P. Björntorp and R. Rössner, editors. John Libbey Company Ltd., London. 15-21.

26. Gaillard, D., G. Ailhaud, and R. Négrel. 1985. Fetuin modulates growth and differentiation of $\mathrm{Ob} 17$ preadipose cells in serum-free hormone supplemented medium. Biochim. Biophys. Acta. 846:181191.

27. Broad, T. M., and R. G. Ham. 1983. Growth and adipose differentiation of sheep preadipocyte fibroblasts in serum-free medium. Eur. J. Biochem. 135:33-39.

28. Serrero, G., and D. Mills. 1987. Differentiation of newborn rat adipocyte precursors in defined serum-free medium. In Vitro. 23:6366.

29. Dani, C., A. Doglio, E. Amri, S. Bardon, P. Fort, B. Bertrand, P. Grimaldi, and G. Ailhaud. 1989. Cloning and regulation of a mRNA specifically expressed in the preadipose state. J. Biol. Chem. In press.

30. Hayashi, I., T. Nixon, and H. Green. 1981. Adipogenic and antiadipogenic factors in the pituitary and other organs. Proc. Natl. Acad. Sci. USA. 78:3969-3972.

31. Ignotz, R. A., and J.. Massague. 1985. Type- $\beta$ transforming growth factor controls the adipogenic differentiation of 3T3 fibroblasts. Proc. Natl. Acad. Sci. USA. 82:8530-8534.

32. Torti, F. M., B. Dieckmann, B. Beutler, A. Cerami, and G. M. Ringold. 1985. A macrophage factor inhibits adipocyte gene expression: an in vitro model of cachexia. Science (Wash. DC). 229:867-869.

33. Navre, M., and G. M. Ringold. 1988. A growth factor-repressible gene associated with protein kinase C-mediated inhibition of adipocyte differentiation. J. Cell Biol. 107:279-286.

34. Björntorp, P., M. Karlsson, P. Pettersson, and G. Sypniewska. 1980. Differentiation and function of rat adipocyte precursor cells in primary culture. J. Lipid Res. 21:714-723.

35. Djian, P., D. A. K. Roncari, and C. H. Hollenberg. 1985. Adipocyte precursor clones vary in capacity for differentiation. Metab. Clin. Exp. 34:880-883.

36. Djian, P., D. A. K. Roncari, and C. H. Hollenberg. 1983. Influence of anatomical site and age on the replication and differen- tiation of rat adipocyte precursors in culture. J. Clin. Invest. 72:12001208.

37. Faust, I. M., P. R. Johnson, J. S. Stern, and J. Hirsch. 1978. Diet-induced adipocyte number increase in adult rats: a new model of obesity. Am. J. Physiol. 235:E279-E286.

38. Hauner, H., M. Wabitsch, and E. F. Pfeiffer. 1988. Differentiation of adipocyte precursor cells from obese and non-obese adult women and from different adipose tissue sites. Horm. Metab. Res. 19(Suppl.):35-39.

39. Rubin, C. S., A. Hirsch, C. Fung, and O. M. Rosen. 1978. Development of hormone receptors and hormonal responsiveness in vitro. Insulin receptors and insulin sensitivity in the preadipocyte and adipocyte forms of 3T3-L1 cells. J. Biol. Chem. 253:7570-7578.

40. Schiwek, D., and G. Löffler. 1987. Glucocorticoid hormones contribute to the adipogenic activity of human serum. Endocrinology. 120:469-474.

41. Spiegelman, B. M., M. Frank, and H. Green. 1983. Molecular cloning of mRNA from 3T3 adipocytes. Regulation of mRNA content for glycerophosphate dehydrogenase and other differentiation-dependent proteins during adipocyte development. J. Biol. Chem. 258:10083-10089.

42. Bernlohr, D. A., M. A. Bolanowski, T. J. Kelly, and M. D. Lane. 1985. Evidence for an increase in transcription of specific mRNAs during differentiation of 3T3-L1 preadipocytes. J. Biol. Chem. 260:5563-5567.

43. Chapman, A. B., D. M. Knight, and G. M. Ringold. 1985. Glucocorticoid regulation of adipocyte differentiation: hormonal triggering of the developmental program and induction of a differentiation-dependent gene. J. Cell Biol. 101:1227-1235.

44. Cook, J. S., J. J. Lucas, E. Sibley, M. A. Bolanowski, R. J. Christy, T. J. Kelly, and M. D. Lane. 1988. Expression of the differentiation-induced gene for fatty acid-binding protein is activated by glucocorticoid and cAMP. Proc. Natl. Acad. Sci. USA. 85:2949-2953.

45. Négrel, R., D. Gaillard, and G. Ailhaud. 1989. Prostacyclin as a potent effector of adipose cell differentiation. Biochem. J. 257:398405. 